\title{
The role of beta-adrenolytic drugs in treating anxiety disorders
}

\author{
Rola leków beta-adrenolitycznych w leczeniu zaburzeń lękowych
}

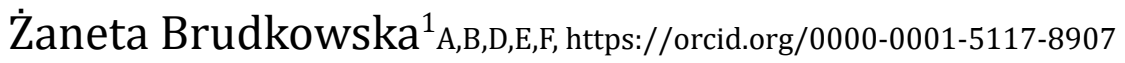

Małgorzata Tomczyk ${ }^{2}$ A,B,D,E,F

Katarzyna Jusiak ${ }^{3}$ B,F https://orcid.org/0000-0001-8304-8867

Hanna Karakuła-Juchnowicz ${ }^{3}$ A,D,E, https://orcid.org/0000-0002-5971-795X

Ewa Rudnicka-Drożak ${ }^{2} \mathrm{~A}, \mathrm{D}, \mathrm{E}$

${ }^{1}$ Department of Clinical Neuropsychiatry, Medical University of Lublin

${ }^{2}$ Chair and Department of Family Medicine, Medical University of Lublin

${ }^{3}$ I Department of Psychiatry, Psychotherapy and Early Intervention, Medical University of Lublin

\section{Summary}

\section{Introduction}

Beta blockers are mainly used in treating cardiovascular diseases. However, it has been observed that these drugs have also an anxiolytic potential. Over the years, a number of clinical trials have been conducted aimed at determining the effectiveness of beta blockers in treating anxiety disorders.

\section{The aim of the article}

The main objective of the article is to present the significance and position of adrenolytic drugs in the pharmacotherapy of anxiety disorders on the basis of available literature. Moreover, the authors also decided to take into account the data from current research results, considering the problem of side effects of using adrenolytic drugs - especially the controversial reports on their effect on the development of affective disorders.

\section{Method}

An analysis was conducted of articles from Medline/PubMed database, selected on the basis of the following key words: anxiety disorders, beta blockers, adrenolytic drugs, as well as on the basis of their dates of publication: 1960-2017. In order to conduct a reliable and complete review of literature, the authors decided to include works from quite an extended period of time. The articles included in the review were published in Polish and English.

\section{Results}

The review of articles concerning the treatment of anxiety disorders clearly suggests that propranolol is effective in reducing the frequency of panic attacks and the tendency for avoidance behavior in patients with agoraphobia. Other studies report on potential benefits in terms of early interventional prevention and treating posttraumatic stress disorder with propranolol. However, there is lack of randomized clinical trials concerning the therapeutic effect of other adrenolytic drugs in treating anxiety disorders. Early research works reported that (mainly lipophilic) beta blockers may have a depressogenic effect; however, the latest studies have not confirmed it. 


\section{Conclusions}

The contemporary research on the therapeutic potential of beta blockers in treating anxiety disorders is insufficient. What seems to be most promising, however, are reports concerning the desirable effects of using adrenolytic drugs in treating posttraumatic stress disorder, which implicates the necessity of conducting further research verifying the validity of their application.

Keywords: adrenolytic drugs, beta blockers, anxiety disorders, posttraumatic stress disorder

\section{Streszczenie}

\section{Wstęp}

Leki $\beta$-adrenolityczne mają główne zastosowanie w leczeniu chorób sercowo-naczyniowych. Zauważono jednak, iż leki te wykazują również potencjał anksjolityczny. Na przestrzeni lat podejmowano kolejne próby kliniczne mające na celu określenie efektywności beta- brokerów w leczeniu zaburzeń lękowych.

\section{Cel pracy}

Nadrzędnym celem artykułu jest przedstawienie na podstawie dostępnej literatury, znaczenia i miejsca leków adrenolitycznych w farmakoterapii zaburzeń lękowych. Ponadto, postanowiono również uwzględnić dane płynące z aktualnych wyników badań rozpatrujące problem efektów ubocznych stosowania leków adrenolitycznych - szczególnie kontrowersyjne doniesienia o wpływie beta-blockerów na rozwijanie się zaburzeń afektywnych.

\section{Metoda}

Analizie poddano artykuły z bazy Medline/PubMed, które wyszukano przy użyciu słów kluczy: zaburzenia lękowe, beta-blokery, leki adrenolityczne i deskryptorów czasowych: 1960 -2017. W celu dokonania rzetelnego i pełnego przeglądu literatury zdecydowano się zastosować dość szeroki zakres czasowy publikowanych prac. Uwzględniono artykuły opublikowane w języku polskim i języku angielskim.

\section{Wyniki}

Przegląd prac dotyczących leczenia zaburzeń lękowych wyraźnie sugeruje, iż propranolol skutecznie redukuje częstotliwość ataków paniki oraz tendencje do zachowań unikowych u pacjentów z agorafobią. Inne badania donoszą o potencjalnych korzyściach w zakresie wczesnej profilaktyki interwencyjnej oraz leczenia propranololem zespołu lęku pourazowego. Brakuje jednak randomizowanych badań klinicznych dotyczących efektu terapeutycznego innych adrenolityków w leczeniu zaburzeń lękowych. Wczesne prace badawcze donosiły, iż beta - blokery (głównie lipofilne) mogą mieć depresjonogenne działanie, ostatnie badania nie potwierdziły jednak tych doniesień.

\section{Wnioski}

Współczesne badania nad potencjałem terapeutycznym beta - blokerów w leczeniu zaburzeń lękowych są niewystarczające. Najbardziej obiecujące jednak wydają się być doniesienia dotyczące pożądanych efektów zastosowania leków adrenolitycznych w leczeniu zespołu lęku pourazowego, co nasuwa konieczność prowadzenia dalszych badań weryfikujących zasadność ich stosowania.

Słowa kluczowe: leki adrenolityczne, beta-blokery, zaburzenia lękowe, zespół stresu pourazowego

\section{Introduction}

The latest edition of the Diagnostic and Statistical Manual of Mental Disorders (DSM-5) groups anxiety disorders in three following categories: "classical" anxiety disorders (e.g. specific phobias, separation anxiety disorder, selective mutism, social phobia, agoraphobia, panic disorder, and generalized anxiety disorder); obsessive-compulsive disorders and the related disorders, and trauma and stressor-related disorders (including PTSD - Posttraumatic Stress Disorder) [1]. Separation anxiety disorder was added to the group of anxiety disorders, while the previous version of DSM suggested that this disorder only affected children [2, $3]$. This change was introduced following the consideration of the results of epidemiological studies which clearly demonstrated an unexpectedly high incidence of separation 
anxiety disorders in adults [4]. Moreover, DSM-5 includes selective mutism in the group of anxiety disorders, while it was earlier listed in the category of other disorders of infancy, childhood or adolescence $[1,5]$.

On the basis of the results of epidemiological studies, it can be concluded that anxiety disorders are the most widespread psychological disorders in the world and they clearly correlate with comorbidity - the presence of somatic diseases [6]. Systematic reviews of studies to date, conducted with meta-regression analysis, suggest that the current global prevalence of anxiety disorders amounts to $7.3 \%$ (ranging from $4.8 \%$ to $10.9 \%$ ) [7, 8]. The estimated total number of persons living with anxiety disorders across the world amounts to 264 million [9]. This number reflects an increase by $14.9 \%$ in 2015 in comparison to 2005 , as a result of growth and aging of the population. In the European Union (EU), over 60 million people are affected by anxiety disorders, which makes them the most widespread psychiatric condition in Europe [10]. Thus, anxiety disorders are the sixth largest factor contributing to global deterioration of health [11]; they significantly reduce quality of life [12] as well as professional effectiveness and productivity [13].

Statistical data inform that anxiety disorders most often have the form of specific phobias (10.3\%) and generalized anxiety disorder (GAD), which affects even as many as $6.2 \%$ of persons with anxiety disorders in the adult population. Other most frequent anxiety disorders also include panic disorders (6.0\%), social anxiety disorder (SAD) and obsessive-compulsive disorder (OCD) [14, 10].

Clinical trials demonstrate that anxiety disorders carry the risk of escalation, as well as the sick developing affective disorders and addictions to psychoactive substances [15]. Untreated anxiety disorders can lead to negative personal and social consequences, such as frequent hospitalizations, reduced work effectiveness, unemployment and disorders in interpersonal relationships [16].

Standard treatment of anxiety disorders involves various types of psychotherapy; however, it is often also necessary to introduce pharmacotherapy. In accordance with the principles presented in medical guides and recommendations, the basis of the pharmacotherapy of anxiety disorders should be antidepressants: selective serotonin reuptake inhibitors (SSRIs), serotoninnorepinephrine reuptake inhibitors (SNRIs) and tricyclic antidepressants (TCA) [17].

\section{Method}

An analysis was conducted of articles from Medline/ PubMed database, selected on the basis of the following key words: anxiety disorders, beta blockers, adrenolytic drugs, as well as on the basis of their dates of publication: 19602017. In order to conduct a reliable and complete review of literature, the authors decided to include works from quite an extended period of time. The articles included in the review were published in Polish and English.

\section{Mechanism of action}

\section{Pharmacological properties and the spectrum of clinical applications of beta blockers}

Beta blockers are an extremely important class of drugs due to unquestionable high frequency of their use, probably related to their versatility and multi-directionality of their effects, especially in cardiovascular diseases [18]. Beta-adrenolytic drugs, also known as beta blockers, are a heterogeneous group of drugs both in terms of their chemical structure and pharmacological properties. Their common mechanism of action consists in blocking beta-adrenergic receptors; however, it has not been clearly understood yet [19].

The theoretical basis of the research into developing beta blockers was Raymond P. Ahlquist's groundbreaking work published in 1948. In this paper, the scientist summarized his findings suggesting that there are two distinct receptors for catecholamines causing different reactions in the cardiac muscle; he called them $\alpha$ - and $\beta$-adrenoceptors [20]. The terms "alpha blockers" and "beta blockers" were suggested for the first time in 1958 by Moran and Perkins [21].

The subsequent step in the history of beta blockers was the discovery made in 1958: that dichloroisoproterenol, synthesized by Eli Lilly Laboratories, exhibits epinephrineinhibiting properties. This compound was considered the first beta blocker. At first, the potential for clinical application of dichloroisoproterenol was overlooked. However, as soon as in the early 1960s, the Scotch pharmacologist James Black (who was awarded the Nobel Prize in Medicine and Physiology for his work on beta blockers) and his collaborators from Imperial Chemical Industries (ICI) in the UK developed new beta blockers: pronethalol and propranolol [23]. These scientists presumed that the above-mentioned compounds could reduce myocardial oxygen consumption through "disrupting" the effects of catecholamines, and thus, could be useful in treating angina pectoris, hypertension and arrhythmia [21]. In the late 1970s and early 1980s, numerous clinical trials demonstrated that beta-adrenolytic drugs reduce the mortality rate in an unselected group of patients after myocardial infarction [24, $25,26,27]$.

In 1982, an article was published describing the results of a study aimed at comparing propranolol and 
hydrochlorothiazide in the initial treatment of arterial hypertension [28]. This paper initiated a debate on pharmacotherapy using beta blockers in hypertension, which continues until today. Later, research was conducted which demonstrated that beta blockers are a safe therapeutic option in treating arrhythmia and chronic congestive heart failure [29].

The continuing evolution of this group of drugs has resulted in producing three generations of beta blockers. The first generation comprises non-selective drugs, the second cardioselective drugs, and the third (the latest generation) - vasodilator drugs.

The basic mechanism of action of beta blockers is their ability to block adrenergic receptors, which occurs through beta blockers competing with catecholamines. It is well known that the sympathetic nervous system has the ability to mobilize the organism and influence blood pressure mainly through the effect of catecholamines. Adrenolytic drugs can attach to beta receptors due to their greater chemical affinity than that of catecholamines. So far, three types of $\beta$ receptors have been described: $\beta 1, \beta 2, \beta 3$. Some researchers point out that there is one more type of $\beta$ receptors (obviously referred to as $\beta 4$ ); however, its structure has not been thoroughly examined yet. Beta-adrenergic receptors can be found in the cell membrane of many organs (and thus demonstrate various effects of stimulation) [30]. The mechanism of action of beta blockers is heterogeneous and not fully understood yet.

"The mechanism of action of $\beta$-adrenolytic drugs at the cell level consists in blocking cell surface receptor coupled to adenylyl cyclase (both $\beta 1$ and $\beta 2$ receptors), that is in inhibiting the so-called second messenger, which is cyclic AMP (cAMP) [3',5'-cyclic adenosine monophosphate]. It indirectly affects, through high-energy phosphorus compounds (ATP) and $\mathrm{Ca}^{2+}$ ions, the contractile protein complex (troponin-actin-myosin), causing the muscle to relax" [31].

The biological effects of adrenolytic drugs include: reducing heart rate, reducing arterial and intraocular pressure, and bronchial smooth muscle contraction (which is a side effect).

Therefore, beta-adrenolytic drugs are mainly used in clinical practice in treating cardiac diseases. Indications for use of beta-adrenolytic drugs in the diseases of the cardiovascular system are very wide (they will be not listed here in detail due to the purpose of the article). Beta blockers are very significant in treating myocardial infarction, as they reduce the risk of death even to $23 \%$ following long-term use [32]. They also increase the survival rate of patients with chronic heart failure [33,34], of those with idiopathic dilated cardiomyopathy and of patients with various types of arrhythmia [35, 36].
Nevertheless, adrenolytic drugs have also been observed to have anxiolytic effects, which will be elaborated on in the subsequent chapter of this work.

\section{The use of beta blockers in treating anxiety disorders}

Anxiety experienced by people can be manifested through many symptoms. The most distinct example will be an acute anxiety episode which can be observed during a panic attack. Finding oneself in a situation which causes anxiety, triggers the process of anxiety response - the activation of the autonomic nervous system leads to the release of adrenaline, cortisol and noradrenaline to the circulatory system. This, in turn, triggers fight-or-flight reactions. However, it should be emphasized that they are non-adaptive, as they are provoked by anxiety and not by the emotion of fear (an actually threatening situation).

Over the recent years, the use of beta blockers as a beneficial therapeutic option in treating anxiety disorders has become the topic of reflections and discussions of many scientists. The discussion was preceded with reports from studies conducted to date on the role of beta-adrenolytic drugs, such as propranolol, in the pharmacotherapy of anxiety disorders.

The anxiolytic potential of propranolol was observed as early as in the 1960s [30]. Turner and GranvilleGrossman accidentally observed its anti-anxiety effect in a situation when an attempt was made to reduce tachycardia caused by hyperthyroidism [37]. Since that moment, the interest in the potential use of propranolol in psychiatry was growing. As early as in the 1960s and 1970s, many studies were conducted aimed at determining the significance of propranolol in treating psychological disorders. Early studies suggested effectiveness of propranolol in relieving the symptoms of severe anxiety [38, 39, 40], but also of mild situational anxiety in stress-inducing situations such as an exam [41, 42], public appearances [43] or the anxiety experienced by surgeons before performing a surgery [44, 45]. Moreover, experimental studies were undertaken in order to identify the effects of this drug in situations of panic attacks. Literature describes a few ways of provoking a panic attack, consisting in a deliberate stimulation of a physiological response through inhalation of $\mathrm{CO} 2$ [46, 47], an infusion of sodium lactate [48, 49], or an injection of cholecystokinin tetrapeptide (CCK-4) [48]. The abovementioned chemical exposures were used in order to control the research project, but they also helped to predict the level of intensity of a panic attack. In a study on healthy participants, anxiety and panic were provoked by breathing in carbon dioxide. It was observed that propranolol administered orally (40 mg) significantly reduced heart rate and other somatic symptoms in the cardiovascular system, 
but it did not have typically anxiolytic benefits [50]. Other works on treating panic disorders and agoraphobia suggest that propranolol is effective in reducing the incidence of panic attacks and the tendency for avoidance behavior in patients with agoraphobia [51]. In spite of this, a meta-analysis of three studies did not reveal any statistically significant differences between the effectiveness of propranolol and benzodiazepines in short-term treatment of panic disorders with or without agoraphobia [52]. Therefore, it seems reasonable to stick to the current guidelines concerning treatment, which recommend using SSRIs as first-line drugs in the pharmacotherapy of panic disorder [53].

Developments in the research on SSRIs, as well as introducing them as first-line drugs in the pharmacological treatment of anxiety disorders, probably contributed to the gradual loss of interest in the use of propranolol in psychiatry. Nevertheless, the psychopharmacological properties of propranolol have lately again become an object of interest of scientists in the context of developments in the knowledge concerning the processing of emotional experiences in the brain $[54,55,56]$. While propranolol was first studied as a drug with general anxiolytic effects, presently the main object of interest is its amnesic effect on the processes of emotional memory. It is well known that emotional experiences play a key role in the development and persistence of various psychological disorders [57]. In the conducted experimental research (placebo-controlled studies), it was demonstrated that blocking the $\beta$-adrenergic system with propranolol selectively impairs functions of the memory process. In a study by Cahill et al., it was observed that propranolol impairs long-term emotional memory, while it does not affect memories devoid of an emotional context [58]. In another experiment, conducted by van Stegeren, similar results were obtained - it was determined that a beta blocker (propranolol) selectively reduced the amount of memorized information with clear emotional content [59]. The authors of these works connect this effect with propranolol's ability to regulate the level of noradrenaline in the brain. It is a drug which is able to cross the blood-brain barrier, and thereby, to affect the central nervous system. As tests using fMRI (functional magnetic resonance imaging) demonstrate, noradrenaline is a significant neurotransmitter affecting the amygdala, which is the key structure in processing emotional information [60, $61,62$,$] . Nevertheless, the most recent study conducted by$ Rimmele et al. demonstrates that propranolol has the ability to reduce the effectiveness of memorizing (not the process of retrieval from memory!) of both emotional and more neutral stimuli [63].

These latest observations create new possibilities of treating posttraumatic stress disorder (PTSD), in which disturbances in memory processes related to the traumatic event are evidently noted. The most recent works confirm that propranolol efficiently reduces the access to emotionally difficult memories with an anxiety component in PTSD. This effect was attributed to the modification of the process of memory consolidation and was related to altered brain activity in the amygdala and hippocampus [64]. A work by Mahabir et al. demonstrated that propranolol may also affect the effectiveness of cognitive functions through modulating the level of stress and agitation [65]. The results of this study showed that cognitive functioning was improved after administering propranolol to patients suffering from PTSD. Other studies also confirmed potential benefits in terms of early interventional prevention as well as later treatment of PTSD with propranolol [66, 67]. According to British guidelines, propranolol may reduce the risk of developing PTSD in persons who have experienced traumatic stress. Research results attest to the preventive effectiveness of propranolol used at a dosage of $120 \mathrm{mg} / \mathrm{d}$ [53].

So far, therapeutic effect of propranolol in anxiety disorders of the type of specific phobias has not been demonstrated [68]. Moreover, there is lack of randomized clinical trials concerning the therapeutic effect of propranolol in treating other anxiety disorders (e.g. generalized anxiety disorder, obsessive-compulsive disorder, separation anxiety disorder, or selective mutism).

Nonetheless, over the years attempts have been made in psychiatry to determine the therapeutic role of also other beta-adrenolytic drugs (apart from propranolol, which is a flagship representative of this group of drugs). Atenolol which is also a beta-1 blocker widely used in cardiology (with non-selective, peripheral effects) relieved the symptoms of anxiety in patients suffering from isolated symptoms of SAD (social anxiety disorder), such as strong anxiety experienced before public appearances (class IV evidence) [69, 54]. In turn, nadolol in clinical trials reduced heart rate and relieved tremors related to experiencing stage fright in situations of public appearances or artistic performances - a similar effect was also observed in pindolol [70, 71]. Another example is betaxolol, which is able (like propranolol) to cross the blood-brain barrier. It has been demonstrated that betaxolol administered orally at a dosage of 5-40 mg daily in treating generalized anxiety disorders (GAD) and other states of anxiety relieved anxiety and acted as a prophylactic, as its effects were sustained for up to a few days (not hours) [73].

The authors of the current work would like to draw particular attention to the significance of treating anxiety disorders co-occurring with diseases of the vascular system. Anxiety is probably the most frequent 
psychopathological symptom in patients after an acute cardiovascular event (it is estimated that $70-80 \%$ patients in this group experience it) [74]. It is also a serious problem in persons who suffer from chronic diseases of the cardiovascular system: around $20-25 \%$ patients in the latter group experience long-term constant anxiety. Anxiety is even more common among people with heart failure (25$50 \%$ patients) [74]. Prevalence of anxiety in coronary artery disease in men ranges from $12.0 \%$ to $41.8 \%$, and from $21.5 \%$ to $63.7 \%$ in women - this study was conducted on a large population and included data from 22 European countries [75]. These statistical observations are an important argument supporting the significance of drawing attention to the problem of comorbidity, or co-occurrence of anxiety disorders and cardiovascular diseases.

The presence of anxiety disorders makes it more difficult for patients to adapt to a troublesome situation caused by a chronic disease, and is related to lower quality of life, more difficulties in understanding and following medical recommendations, and slower recovery after acute cardiovascular events [76, 77, 78].

Anxiety is a risk factor for developing cardiovascular diseases, but also for myocardial infarction complications (arrhythmias or subsequent episodes of myocardial infarction) and is also related to a higher mortality rate in this group of patients [77]. Moreover, the value of this risk is directly proportional to the severity of anxiety [79]. However, the pathogenic bases for the relationship between anxiety and a poor prognosis in heart attack are not fully understood yet. Moser suggests that physiological (e.g. the activation of the sympathetic nervous system) and behavioral (e.g. worse cooperation during treatment) correlates of anxiety can be linked to unsatisfactory results of therapy [80, 81]. $\mathrm{He}$ also indicates that this problem seems to be specific for myocardial infarction; however, the data concerning the effect of anxiety on prognoses in other cardiovascular diseases are not unambiguous.

Although beta blockers are first choice drugs in many cardiac diseases, and at the same time they have anxiolytic potential, studies to date suggest that in cases of comorbidity (of anxiety disorders and cardiovascular diseases), typical anti-anxiety drugs such as SSRIs, SNRIs and TCAs should also be included in treatment [82].

\section{Risk factors related to using adrenolytic drugs in the pharmacotherapy of anxiety disorders}

Using beta blockers in psychiatry involves a lot of controversy. There is certain evidence supporting the use of beta blockers in treating panic disorder and PTSD; however, it is not recommended to apply them in the treatment of other forms of anxiety [83]. It was demonstrated in a number of casuistic works that metoprolol can cause anxiety in elderly patients, which is relieved or subsides after the drug is discontinued [84]. One of the reasons behind it is the fact that beta blockers such as metoprolol and propranolol are lipophilic and can cross the bloodbrain barrier [84]. Lipophilic adrenolytic drugs are also metabolized by the liver, which is an important aspect as far as elderly patients affected by heart or liver diseases are concerned [85]. Moreover, there is a number of other psychoactive drugs which can influence the effectiveness of beta blockers and their side effects. Drugs from the SSRI group may increase the concentration of beta-adrenolytic drugs in blood plasma. However, tricyclic antidepressants can increase their antihypertensive effect [85]. For this reason, beta blockers are not recommended to be used in anxiety disorders in geriatric patients. Moreover, a work by Molden and Spigset demonstrates that metoprolol should not be used with paroxetine, fluoxetine or bupropion due to their high interaction potential and the risk of serious side effects [86]. Dose reduction of metoprolol should be considered when it is used together with citalopram, escitalopram or duloxetine, while its use together with sertraline, venlafaxine, mianserin and mirtazapine should be safe [86]. It has been demonstrated that paroxetine is a strong inhibitor of CYP2D6 and increases the biologically available dose of metoprolol by around 4 to 6 times. A similar effect can be expected with the use of another two strong inhibitors of CYP2D6 in this class: fluoxetine and bupropion [86]. Severe bradycardia and atrioventricular block were observed in patients who took metoprolol together with the three above-mentioned drugs. Escitalopram, citalopram and duloxetine are weaker inhibitors of CYP2D6 and it has been demonstrated that they cause the biologically available dose of metoprolol to be increased by 2 to 3 times. Other antidepressants, such as sertraline, venlafaxine, mianserin and mirtazapine, inhibit CYP2D6 to a low degree or do not inhibit it at all; thus, it is not expected that they will cause clinically significant reactions with metoprolol [86].

A frequently mentioned risk factor of using beta blockers is depression, though current evidence from studies conducted to date has been contradictory. Research results are available which confirm the negative effect of beta-adrenolytic drugs on the general wellbeing and mood among patients treated with these drugs due to arterial hypertension [87]. In another study, metoprolol aggravated the symptoms of depression and the level of burnout syndrome, but it had anxiolytic benefits independent of the reduction of heart rate in patients with chronic heart 
failure with clinical symptoms of psychological disorders [88]. For this reason, doctors should be cautious when prescribing metoprolol to patients with chronic heart failure whose medical history includes experiencing psychological disorders.

In the meta-analysis which concerned 15 randomized studies on 35,000 patients taking beta-adrenolytic drugs in the treatment of myocardial infarction, heart failure or arterial hypertension, no statistically significant difference was demonstrated between beta blockers and placebo in regard to the symptoms of depression. Moreover, beta blockers were linked to an increased frequency of experiencing tiredness and sexual dysfunctions [89].

On the basis of these observations, a hypothesis was put forward that lipophilic drugs (such as propranolol, metoprolol) are related to a greater frequency of symptoms from the central nervous system, such as tiredness and depression, due to their ability to penetrate to the central nervous system. In subsequent studies, it was demonstrated that the solubility of beta-adrenolytic drugs in lipids did not cause an increase in the risk of side effects in the form of psychological disorders [89].

In turn, the risk of tiredness, but not depression or sexual dysfunctions, was greater (relative risk 1.78, 95\% CI 1.08-2.93) in comparison to later generation beta blockers [89]. It should be emphasized that the number of samples was small and confidence intervals were quite wide.

In another publication which was the result of multicenter studies, Beck Depression Inventory was used to estimate the occurrence of the symptoms of depression in patients after myocardial infarction. In 254 patients taking beta blockers and 127 patients not treated with them, the study did not reveal a statistically significant difference between these two groups with regard to the occurrence of depression after 3, 6 and 12 months after myocardial infarction [90]. Similar results were obtained in a publication by Ranchord et al., also concerning patients after myocardial infarction; the article did not confirm an increase in depression symptoms after 1, 6 and 12 months of beta-blocker therapy [91]. In this study, depression symptoms were evaluated using an 8-item personal health questionnaire (PHQ-8) in 3,190 persons on beta-blocker therapy and in 280 patients not using these drugs after myocardial infarction [91]. Kent et al. suggested that beta blockers can cause depression more often in women than in men [92]. However, Crane et al. studied a cross-section sample of 84 women (over 65 years old) from 6 to 12 months after myocardial infarction and did not identify an increased risk of depression (with the use of Geriatric Depression Scale) in women taking beta-adrenolytic drugs [93].
Typical undesirable side effects of cardiological betaadrenolytic drugs include: bradycardia, reduced exercise capacity, hypotension, atrioventricular block. Other typical side effects include nausea, vomiting, discomfort in the abdomen, dizziness, infirmity, headache, tiredness, oral and ocular dryness. Less frequent undesirable side effects include sexual disorders, memory loss and disorientation $[94,95]$.

In spite of the fact that side effects of beta-adrenolytic drugs occur less frequently in comparison to SSRIs (e.g. $1-10 \%$ are sleep disorders, nightmares, temporary tiredness and cold limbs), it would seem reasonable not to depart from the current guidelines recommending SSRIs as firstline drugs in treating anxiety disorders until reliable data concerning comparative effectiveness and tolerance of both these groups of drugs are available [54].

\section{Summary}

The results of studies to date presented above indicate that adrenolytic drugs have certain anxiolytic potential. An analysis of articles concerning the treatment of panic disorders and agoraphobia suggests that especially propranolol is effective in reducing the frequency of panic attacks and the tendency for avoidance behavior in patients with agoraphobia. In turn, numerous studies confirmed potential benefits in terms of early intervention and later treatment of PTSD with propranolol. In spite of this, therapeutic effect of propranolol in anxiety disorders of the type of specific phobias has not been demonstrated so far. Moreover, there is a lack of randomized clinical trials concerning the therapeutic effect of propranolol in treating other anxiety disorders. Studies into other betaadrenolytic drugs indicate that e.g. atenolol relieves the symptoms of anxiety in patients suffering from isolated symptoms of social anxiety disorder (SAD). In turn, nadolol reduced symptoms of stage fright in situations of public appearances and artistic performances; a similar effect was also observed in pindolol. Using beta blockers, mainly lipophilic (e.g. propranolol, metoprolol), is related to an increased prevalence of symptoms linked to the central nervous system (such as the constant feeling of tiredness and depression) due to the ability of these drugs to penetrate to the central nervous system, although there are also works which disprove this thesis.

In conclusion, although beat-adrenolytic drugs have a certain anxiolytic potential, they require further testing (in clinical trials) in order to measure the level of their therapeutic effectiveness, taking into consideration particular types of anxiety disorders. 
Wstęp

Zaburzenia lękowe w najnowszej edycji podręcznika DSM-5 (Diagnostic and Statistical Manual of MentalDisorders) zostały ujęte $\mathrm{w}$ trzech, następujących kategoriach: „klasyczne” zaburzenia lękowe (np.: fobie specyficzne, zaburzenie lęku separacyjnego, mutyzm selektywny, specyficzna fobia, fobia społeczna, agorafobia, zaburzenie paniczne oraz i uogólnione zaburzenie lękowe); zaburzenia obsesyjno-kompulsywne i zaburzenia z nimi powiązane oraz zaburzenia urazowe i związane ze stresem (między innymi: PTSD - Posttraumatic Stress Disorder) [1]. Grupa zaburzeń lękowych została rozszerzona o zaburzenie lęku separacyjnego, poprzednia wersja DSM sugerowała, iż zaburzenie to dotyczy tylko dzieci [2, 3]. Zmiana została wprowadzona uwzględniając wyniki badań epidemiologicznych, które wyraźnie wykazały nieoczekiwanie wysoką częstotliwość występowania zaburzeń lęku separacyjnego u osób dorosłych [4]. Ponadto DSM-5 wprowadza także selektywny mutyzm do grupy zaburzeń lękowych, wcześniej ujmowany w kategorii innych zaburzeń wieku niemowlęcego, dzieciństwa lub adolescencji $[1,5]$.

Na podstawie wyników badań epidemiologicznych można stwierdzić, iż zaburzenia lękowe są najbardziej rozpowszechnionymi zaburzeniami psychicznymi na całym świecie i wyraźnie korelują z współchorobowością - obecnością chorób somatycznych [6]. Systematyczne przeglądy dotychczasowych badań prowadzone wraz z analizą meta-regresji sugerują, iż aktualna globalna częstość występowania zaburzeń lękowych wynosi 7,3\% (4,8\% do 10,9\%) [7, 8]. Łączna szacunkowa liczba osób żyjących z zaburzeniami lękowymi na świecie sięga 264 milionów [9]. Ta suma w 2015 r. odzwierciedla wzrost o 14,9\% od 2005 r. w wyniku wzrostu liczby ludności i starzenia się społeczeństw. W Unii Europejskiej (UE) ponad 60 milionów ludzi jest dotkniętych zaburzeniami lękowymi, co czyni je najbardziej rozpowszechnionymi schorzeniami psychiatrycznymi w Europie [10]. Zaburzenia lękowe są więc szóstym co do wielkości czynnikiem przyczyniającym się do globalnej utraty zdrowia [11], znacznie obniżają jakość życia [12] oraz efektywność i produktywność zawodową [13].

Dane statystyczne informują, iż zaburzenia lękowe najczęściej występują w postaci fobii specyficznych (10.3\%) oraz GAD (ang. generalized anxiety disorder) czyli zaburzenia lęku uogólnionego, które dotyka nawet 6,2\% chorych z zaburzeniami lękowymi populacji dorosłych osób. Wśród najczęściej występujących zaburzeń lękowych wymienia się także zaburzenie z napadami paniki $(6.0 \%)$, fobie społeczne SAD (ang. social anxiety disorder) i OCD (ang. obsessive - compulsivedisorder) [14, 10].
Badania klinicznie wskazują, iż zaburzenia lękowe niosą ze sobą ryzyko ich eskalacji a także powstawania u chorych zaburzeń afektywnych oraz rozwoju uzależnień od substancji psychoaktywnych [15]. Nieleczone zaburzenia lękowe wiążą się z negatywnymi konsekwencjami osobistymi oraz społecznymi takimi jak: częste hospitalizacje, zmniejszoną wydajnością w pracy, bezrobociem i zaburzeniami relacji interpersonalnych [16].

Standardowe leczenie zaburzeń lękowych obejmuje różnego rodzaju oddziaływania psychoterapeutyczne, często jednak niezbędne jest wdrożenie również farmakoterapii. Zgodnie $\mathrm{z}$ zasadami prezentowanymi w podręcznikach i wytycznych podstawą farmakoterapii zaburzeń lękowych powinny być leki przeciwdepresyjne: selektywne inhibitory wychwytu zwrotnego serotoniny (ang. selective serotonin reuptakeinhibitors, SSRI), inhibitory wychwytu zwrotnego noradrenaliny i serotoniny (ang. serotonin-norepinephrinereuptakeinhibitors, SNRI) oraz trójpierścieniowe leki przeciwdepresyjne (TLPD) [17].

\section{Metoda}

Analizie poddano artykuły z bazy Medline/PubMed, które wyszukano przy użyciu słów kluczy: zaburzenia lękowe, beta-blokery, leki adrenolityczne i deskryptorów czasowych: 1960-2017. W celu dokonania rzetelnego i pełnego przeglądu literatury zdecydowano się zastosować dość szeroki zakres czasowy publikowanych prac. Uwzględniono artykuły opublikowane w języku polskim i języku angielskim.

\section{Mechanizm działania}

\section{Właściwości farmakologiczne i spektrum kliniczne zastosowania beta-blokerów}

Beta-blokery są niezwykle ważną klasą leków ze względu na ich niewątpliwie dużą częstość zastosowywania, która prawdopodobnie wiąże się z ich wszechstronnością i wielokierunkowością działania szczególnie w chorobach sercowo-naczyniowych [18]. Leki beta-adrenolityczne, określane również jako beta-adrenolityki lub beta-blokerysą heterogenną grupą leków zarówno pod względem budowy chemicznej, jak i właściwości farmakologicznych. Wspólnym mechanizmem ich działania jest blokada receptora $\beta$ adrenergicznego, niemniej jednak nie został on jeszcze dokładnie poznany [19].

Podstawę teoretyczną badań nad opracowywaniem leków beta-adrenolitycznych stanowiła przełomowa praca Raymonda P. Ahlquist'a opublikowana w 1948 r. Badacz podsumował w niej swoje odkrycia wskazujące, iż istnieją dwa różne receptory dla katecholamin, powodujące 
różne reakcje $\mathrm{w}$ mięśniu sercowym, nazwał je $\alpha$ i $\beta$-adrenoceptorami [20]. Pojęcia: „alfa-bloker” oraz „betabloker" zostały po raz pierwszy zaproponowane w roku 1958 r. przez Morana i Perkinsa [21].

Kolejnym krokiem w historii beta - brokerów było odkryciew 1958 r., iż zsyntetyzowany przez Eli Lilly Laboratories dichloroizoproterenol wykazuje właściwości hamujące aktywność epinefryny, związek ten został uznany za pierwszy beta-bloker [22]. Początkowo nie doceniano potencjalności zastosowania klinicznego dichloroizoproterenolu. Już jednak na początku lat sześćdziesiątych James Black, szkocki farmakolog (otrzymał nagrodę Nobla w dziedzinie medycyny i fizjologii za pracę nad beta-blokerami) i jego współpracownicy z Imperial Chemical Industries (ICI) w Wielkiej Brytanii opracowalikolejne związki $\beta$-adrenergiczne: pronetalol i propranolol [23]. Badacze ci przypuszczali, iż wyżej wymienione związki mogą obniżać zużycie tlenu przez mięśnie sercowe, poprzez „zakłócanie” działania katecholamin, a zatem mogłoby być użyteczne w leczeniu dusznicy bolesnej, nadciśnienia i arytmii [21]. Pod koniec lat siedemdziesiątych i na początku lat osiemdziesiątych, liczne badania kliniczne udowodniły, że leki $\beta$-adrenolityczne zmniejszają śmiertelność w niewyselekcjonowanej grupie chorych, którzy przebyli zawał serca [24, 25, 26, 27].

W roku 1982 r. ukazał się artykuł opisujący wyniki badań, których celem było porównanie propranololu i hydrochlorotiazydu w początkowym leczeniu nadciśnienia tętniczego [28]. Praca zainicjowała dyskusję nad tematem farmakoterapii z zastosowaniem adrenolityków typu beta w nadciśnieniu, która trwa do chwili obecnej. W późniejszym czasie wykonano badania, z których wynikało, iż betaadrenolityki są bezpieczną opcją terapeutyczną w leczeniu arytmii serca oraz przewlekłej, zastoinowej niewydolności serca [29].

Stała ewolucja tej grupy leków sprawiła, iż aktualnie wyróżnia się trzy generacje beta- adrenolityków. Pierwsza generacja to leki nieselektywne, druga leki selektywne w stosunku do serca oraz trzecia (najnowsza generacja) leki naczyniorozszerzające.

Podstawowym mechanizmem działania betablokerów jest ich zdolność do blokowania receptorów adrenergicznych, odbywa się to poprzez współzawodnictwo beta-blokerów z katecholaminami. Wiadomo, iż układ współczulny ma zdolność mobilizowania organizmu i wpływania na ciśnienie krwi głównie za sprawą działania katecholamin. Leki adrenolityczne potrafią łączyć się z receptorami $\beta \mathrm{w}$ związku $\mathrm{z}$ większym powinowactwem niż wykazują katecholaminy. Do tej pory opisano trzy typy receptorów $\beta$ : $\beta 1, \beta 2, \beta 3$. Niektórzy badacze podkreślają, iż istnieje jeszcze jeden typ receptorów $\beta$ (określają go oczywiście jako $\beta 4$ ) niemniej jednak jego struktura nie została dokładnie poznana. Receptory $\beta$ - adrenergiczne znajdują się $\mathrm{w}$ błonie komórkowej wielu narządów (w związku z tym wykazują rożne efekty pobudzenia) [30]. Mechanizm działania betablokerów (BBL) jest heterogeniczny, nie do końca poznany.

„Działanie leków $\beta$-adrenolitycznych na poziomie komórki, polega na blokowaniu błonowego receptora, połączonego z cyklazq̨ adenylowa (zarówno receptor $\beta 1$, jak i $\beta 2)$, a więc hamowaniu tzw. drugiego przekaźnika (secondomessenger), którym jest cykliczny AMP (c-AMP) [Cykliczny adenozyno-3',5'-monofosforan]. Wpływa to pośrednio, przez wysokoenergetyczne zwiq̨zi fosforowe (ATP) i jony $\mathrm{Ca}^{2+}$, na układbiałek kurczliwych (troponinaaktyna-miozyna), powodując rozkurcz mięśniówki." [31].

Efekty biologiczne działania adrenolityków to między innymi: zmniejszenie częstotliwości akcji serca, obniżenie wartości ciśnienia tętniczego i śródgałkowego oraz (co jest skutkiem ubocznym) skurcz mięśni gładkich oskrzeli.

W praktyce klinicznej beta-adrenolityki znajdują więc głównie zastosowanie w leczeniu chorób kardiologicznych. Wskazania do stosowania leków beta-adrenolitycznych w chorobach układu sercowo-naczyniowego są bardzo szerokie (z uwagi na cel artykułu nie zostaną tutaj szczegółowo wymienione). Beta-blokery mają bardzo duże znaczenie w leczeniu zawału mięśnia sercowego, zmniejszając ryzyko zgonu po długotrwałym stosowaniu nawet do $23 \%$ [32]. Zwiększają również przeżywalność pacjentów z przewlekłą niewydolnością serca [33, 34] $\mathrm{z}$ idiopatyczną kardiomiopatiąrozstrzeniową oraz [35] pacjentów z różnymi typami arytmii [36].

Niemniej jednak zaobserwowano również przeciwlękowe działanie leków adrenolitycznych, co zostanie szerzej przedstawione $\mathrm{w}$ kolejnym rozdziale tej pracy.

\section{Zastosowanie beta-adrenolityków w leczeniu zaburzeń lękowych}

Doświadczany przez człowieka lęk może uzewnętrzniać się poprzez wiele symptomów. Najbardziej wyrazistym przykładem będzie tu ostry epizod lękowy, jaki możemy zaobserwować w sytuacji napadu lęku panicznego. Znalezienie się w sytuacji powodującej lęk uruchamia proces lękowego reagowania - aktywacja układu autonomicznego prowadzi do uwalniania adrenaliny, kortyzolu oraz noradrenaliny do krwioobiegu. Co z kolei implikuje reakcje związane ze schematem „walcz lub uciekaj”. Należy jednak podkreślić, iż są one nieadaptacyjne, ponieważ powstają w wyniku lęku, a nie emocji strachu (realnie zagrażającej sytuacji). 
$\mathrm{Na}$ przestrzeni ostatnich lat zastosowanie betablokerów jako użytecznej terapeutycznej opcji w leczeniu zaburzeń lękowych stawało się tematem rozważań oraz dyskusji wielu badaczy. Dyskusja była poprzedzona doniesieniami z przeprowadzonych dotychczas badań nad rolą leków beta - adrenolitycznych takich jak np.: propranolol w farmakoterapii zaburzeń lękowych.

Anksjolityczny potencjał propranololu został zauważony już w latach 60-tych XX wieku [30]. Turner i Granville-Grossman przypadkowo zauważyli jego działanie przeciwlękowe przy próbie redukowania tachykardii spowodowanej nadczynnością tarczycy [37]. Od tego czasu zwiększyło się zainteresowanie potencjalnością zastosowania propranololu w psychiatrii. Już w latach 60tych oraz 70-tych XX wieku przeprowadzono wiele badań mających na celu dookreślenie znaczenia propranololu w leczeniu zaburzeń psychicznych. W przeprowadzonych wczesnych badaniach postulowano efektywność propranololu w łagodzeniu objawów silnego lęku [38, 39, 40], ale również łagodnych sytuacyjnych stanów niepokoju i lęku w stresogennych sytuacjach jak np.: egzamin [41, 42], wystąpienia publiczne [43], czy lęk odczuwany przez chirurgów przed przeprowadzeniem zabiegu operacyjnego $[44,45]$. Podejmowano również badania eksperymentalne w celu zidentyfikowania efektów działania tego leku w przypadku ataków lęku panicznego. W literaturze opisano kilka sposobów prowokacji ataku paniki, w których celowo stymulowano odpowiedź fizjologiczną poprzez inhalację CO2 [46, 47], wlew mleczanu sodu [48, 49], lub zastrzyk tetrapeptydemcholecystokininy (CCK-4) [48, 50]. Powyżej wymienione ekspozycje chemiczne były używane zastosowano w celu kontrolowania projektu badania, ułatwiały również przewidywanie poziomu nasilenia lęku panicznego. $\mathrm{W}$ badaniu ze zdrowymi ochotnikami, za pomocą inhalacji dwutlenku węgla wywoływano panikę i niepokój. Okazało się, iż propranololpodany doustnie (40mg) znacznie zmniejszał częstość akcji serca oraz inne objawy somatyczne z układu sercowo-naczyniowego, ale nie zapewniał korzyści typowo anksjolitycznych [51]. Inne prace dotyczące leczenia zaburzeń lęku panicznego i agorafobii sugerują, iż propranolol skutecznie redukuje częstotliwość ataków paniki oraz zmniejsza tendencje do zachowań unikowych upacjentów z agorafobią [52]. Pomimo tego meta - analiza z trzech badań nie wykazały statystycznie istotnych różnic między skutecznością propranololu i benzodiazepin w krótkotrwałym leczeniu zespołu lęku napadowego z agorafobią lub bez niej [53]. Dlatego wydaje się, że najrozsądniej byłoby nie odchodzić od aktualnych wytycznych dotyczących leczenia, zalecających stosowanie SSRI jako leków pierwszego rzutu w farmakoterapii zespołu lęku napadowego [54].
Rozwój badań nad lekami z grupy SSRI oraz wprowadzenie ich, jako pierwszej linii leczenia farmakologicznego zaburzeń lękowych prawdopodobnie przyczyniły się do stopniowego spadku uwagi poświęcanej propanolowi w psychiatrii. Niemniej jednak w ostatnim czasie psychofarmakologiczne właściwości propranololu na nowo stały się przedmiotem zainteresowania badaczy w kontekście rozwoju wiedzy dotyczącej przetwarzania doświadczeń emocjonalnych w mózgu [55, 56, 57]. Podczas, gdy propranolol był najpierw badany jako lek o ogólnym działaniu anksjolitycznym, obecnie głównym przedmiotem zainteresowania jest jego amnezyjny wpływ na proces emocjonalnej pamięci. Wiadomo, iż doświadczenia emocjonalne odgrywają kluczową rolę $\mathrm{w}$ rozwoju i utrzymywaniu się szeregu zaburzeń psychicznych [58]. W przeprowadzonych badaniach eksperymentalnych (kontrolowanych placebo) wykazano, iż blokada układu $\beta$-adrenergicznego za pomocą propranololu wybiórczo upośledzała funkcje procesu pamięci. W badaniu Cahill i współ. zaobserwowano, iż propranolol zaburza emocjonalną pamięć długotrwałą, nie wpływa natomiast na pamięć informacji pozbawionych emocjonalnego kontekstu [59]. W kolejnym eksperymencie przeprowadzonym przez van Stegeren i współ. uzyskano podobne wyniki - okazało się, że beta-bloker (propranolol) selektywnie redukowałilość zapamiętanychinformacji niosących wyraźny ładunek emocjonalny [60]. Autorzy prac wiążą ten efekt z zdolnością propranololu do regulowania poziomu noradrenaliny w mózgu, jest on lekiem, który ma zdolność przekraczania bariery krew - mózg, a co się z tym wiąże oddziaływania na CNS. Jak dowodzą badania $\mathrm{z}$ zastosowaniem fMRI (ang. functional magnetic resonance imaging), noradrenalina jest istotnym neurotransmiterem oddziałującym na ciało migdałowate - strukturę kluczową w procesie przetwarzania emocjonalnych informacji [61, 62, 63]. Niemniej jednak najnowsze badanie przeprowadzone przez Rimmele i współ. donosi, iż propranolol wykazuje zdolność obniżania sprawności zapamiętywania (nie procesu odtwarzania pamięciowego!) bodźców zarówno emocjonalnych, jak i tych o bardziej neutralnym charakterze [64].

Te ostatnie spostrzeżenia mogą stwarzają nowe możliwości leczenia zespołu stresu pourazowego (PTSD), gdzie ewidentnie obserwuje się zaburzenia $\mathrm{w}$ zakresie procesu pamięci związane $\mathrm{z}$ traumatycznym wydarzeniem. W najnowszych pracach znajdujemy potwierdzenie, iż propranolol skutecznie zmniejsza dostęp do emocjonalnie trudnych wspomnień z komponentą lęku w PTSD. W najnowszych pracach znajdujemy potwierdzenie, iż propranolol skutecznie zmniejsza dostęp do emocjonalnie trudnych wspomnień z komponentą lęku w zespole stresu pourazowego, ten efekt został przypisany modyfikacji 
procesu rekonsolidacji pamięci i wiązał się ze zmienioną aktywnością mózgu w ciele migdałowatym i hipokampie [65]. W pracy Mahabir i współ. wykazano ze propranolol może również wpływać na sprawność funkcji poznawczych poprzez modulowanie poziomu stresu i pobudzenia [66]. Wyniki tego badania wykazały, że funkcjonowanie poznawcze uległo poprawie po podaniu propranololu pacjentom cierpiącym na PTSD. Inne badania również potwierdziły potencjalne korzyści w zakresie wczesnej profilaktyki interwencyjnej jak i późniejszego leczenia PTSD propranololem $[67,68]$. Wg brytyjskich wytycznych propranolol może zmniejszać ryzyko rozwinięcia się PTSD u osób, które doświadczyły stresu traumatycznego. Wyniki badań świadczą o profilaktycznej skuteczności propranololu stosowanego w dawce $120 \mathrm{mg} / \mathrm{d}$ [53].

Dotychczas nie wykazano terapeutycznego działania propranololu w zaburzeniach lękowych o typie fobii specyficznych [69]. Brakuje również randomizowanych badań klinicznych dotyczących efektu terapeutycznego propranololu w leczeniu innych zaburzeń lękowych np. uogólnionego zaburzenia lękowego (GAD), zaburzenia obsesyjno-kompulsywnego (OCD), zaburzenia lęku separacyjnego lub mutyzmu selektywnego.

Niemniej jednak na przestrzeni lat na gruncie psychiatrii próbowano określić terapeutyczną rolę również innych beta-adrenolityków (poza propranololem, który jest sztandarowym przedstawicielem tej grupy leków). Atenolol - również powszechnie stosowany w kardiologii beta 1-bloker (o działaniu nieselektywnym, peryferyjnym) łagodził objawy lęku u pacjentów cierpiących z powodu izolowanych objawów SAD (ang. socialanxietydisorder) np.: silnego niepokoju przed wystąpieniami publicznymi (dane klasy IV) [70, 54]. Z kolei w nadolol w próbach klinicznych zmniejszał tętno i łagodził objawy drżenia związanego $\mathrm{z}$ doświadczaniem tremy $\mathrm{w}$ sytuacjach wystąpień publicznych, artystycznych [71, 72] - zbliżone działanie wykazywał również pindolol [73]. Innym przykładem jest betaxolol, który może (podobnie jak propranolol) przekraczać barierę krew - mózg. Wykazano, iż dzienny doustny betaxalol podawany w dawce 5 - $40 \mathrm{mg}$ na dobę w leczeniu uogólnionych zaburzeń lękowych (GAD) i innych stanów związanych z lękiem łagodził lęk i niepokój, działał profilaktycznie, ponieważ efekty utrzymywały się do kilku dni (nie godzin) [74].

Autorzy niniejszej pracy chcieliby zwrócić szczególną uwagę na znaczenie leczenia zaburzeń lękowych współwystępujących z chorobami układu krążeniowonaczyniowego.

Lęk jest prawdopodobnie najczęstszym psychopatologicznym objawem u pacjentów po ostrym epizodzie sercowo-naczyniowym (szacuje się, iż doświadcza tego 70-80\% pacjentów w tej grupie) [75]. Jest to również poważny problem u tych, którzy cierpią na przewlekłe choroby ze strony układu sercowo-naczyniowego, ok. 20-25\% pacjentów w tej drugiej populacji doświadcza długotrwałego, ciągłego niepokoju. Wśród osób z niewydolnością serca niepokój jest jeszcze częstszy (25-50\% pacjentów) [75]. Częstość występowania lęku w chorobie wieńcowej wśród mężczyzn waha się od $12,0 \%$ do $41,8 \%$ u kobiet od $21,5 \%$ do $63,7 \%$ - badanie to przeprowadzono na dużej populacji, włączając dane z 22 krajów Europy [76]. Te statystyczne obserwacje są ważnym argumentem wspierającym istotność zwrócenia uwagi na problem współchorobowości, czyli współwystępowania zaburzeń lękowych oraz chorób układu krążenia.

Obecność zaburzeń lękowych utrudnia pacjentom ich adaptację do trudnej sytuacji spowodowanej przewlekłą chorobąi wiąże się z niższą jakością życia, większą trudnością w absorbowaniu i stosowaniu się do zaleceń lekarskich, oraz wolniejszym powrotem do zdrowia po ostrych epizodach sercowo - naczyniowych [76, 77, 78]. Lęk jest czynnikiem ryzyka rozwoju chorób sercowo - naczyniowych, ale także wystąpienia powikłań zawału serca (arytmie lub kolejne epizody zawału serca) i jest również związany z większą śmiertelnością $w$ tej grupie pacjentów [77]. Co więcej, wartość tego ryzyka jest bezpośrednio proporcjonalna do ciężkości lęku [79]. Patogeniczne podstawy dla związku między lękiem a złym rokowaniem w zawale serca nie są jednak dokładnie poznane. Moser sugeruje, że fizjologiczne (na przykład aktywacja współczulnego układu nerwowego) i behawioralne (na przykład gorsza współpraca podczas leczenia) korelaty lęku mogą być połączone $\mathrm{z}$ niezadowalającym wynikiem terapii $[80,81]$. Wskazuje również, że ten problem wydaje się być specyficznym dla zawału serca, jednak dane dotyczących wpływu lęku na prognozy w innych chorobach sercowo-naczyniowych są niejednoznaczne.

Pomimo, iż beta-blokery są lekami pierwszego wyboru w wielu chorobach kardiologicznych, a jednocześnie wykazują potencjał anksjolityczny, dotychczasowe badania sugerują, iż w przypadku współchorobowości (zaburzeń lękowych oraz chorób sercowo-naczyniowych) należy włączyć w proces leczenia również leki o działaniu typowo przeciwlękowym, czyli SSRI, SNRI, TCA [82].

\section{Czynniki ryzyka związane ze stosowaniem adrenolityków w farmakoterapii zaburzeń lękowych.}

Zastosowanie beta-blokerów w psychiatrii niesie ze sobą wiele kontrowersji. Istnieją pewne dowody popierające stosowanie beta-blokerów w leczeniu lęku panicznego oraz PTSD, jednak wdrażanie ich nie jest wskazane w leczeniu 
innych form lęku [83]. W kilku pracach kazuistycznych wykazano, że metoprolol może wywoływać lęk u pacjentów w podeszłym wieku, który łagodzi się lub ustępuje po odstawieniu leku [84]. Jedną z przyczyn wyjaśniających jest to, że beta-blokery, takie jak metoprolol i propranolol, są lipofilne i dlatego mogą przenikać przez barierę krew-mózg [84]. Lipofilneadrenolityki są również metabolizowane przez wątrobę, co jest ważnym aspektem u starszych pacjentów obciążonych chorobami serca lub wątroby [85]. Ponadto istnieje kilka innych leków psychoaktywnych, które mogą wpływać na skuteczność beta-blokerów oraz na ich działania niepożądane. Leki z grupy SSRI mogą zwiększać stężenie beta-adrenolityków w osoczu. Tymczasem trójcykliczne leki przeciwdepresyjne mogą zaostrzyć ich działanie hipotensyjne [85]. Z tego względu beta-blokery nie są zalecane do stosowania w zaburzeniach lękowych u pacjentów geriatrycznych. Ponadto w pracy Molden i Spigseta wykazano, że metoprololu nie należy stosować jednocześnie z paroksetyną, fluoksetyną lub bupropionem ze względu na duże interakcje i ryzyko wystąpienia poważnych działań niepożądanych [86]. Należy rozważyć zmniejszenie dawki metoprololu w skojarzeniu z citalopramem, escitalopramem lub duloksetyną, podczas gdy jednoczesne stosowanie z sertraliną, wenlafaksyną, mianseryną i mirtazapiną powinno być bezpieczne [83]. Wykazano, że paroksetyna jest silnym inhibitorem CYP2D6 i zwiększa biologicznie dostępną dawkę metoprololu około 4- do 6-krotnie. Podobnego efektu możemy spodziewać się przy stosowaniu dwóch innych, silnych inhibitorów CYP2D6 w tej klasie: fluoksetyny i bupropionu [86]. U pacjentów, którzy przyjmowali metoprolol w skojarzeniu z wyżej wymienionymi trzema lekami, obserwowano ciężką bradykardię i blok przedsionkowo-komorowy. Escitalopram, citalopram i duloksetyna są słabszymi inhibitorami CYP2D6 i wykazano, że powodują 2- do 3-krotne zwiększenie biologicznie dostępnej dawki metoprololu. Inne leki przeciwdepresyjne, takie jak sertralina, wenlafaksyna, mianseryna i mirtazapina, hamują CYP2D6 w niewielkim lub w żadnym stopniu i nie oczekuje się, że wywołają klinicznie istotne interakcje z metoprololem [86].

Często wymienianym czynnikiem ryzyka stosowania beta-blokerów jest depresja, chociaż obecne dowody, pochodzące $\mathrm{z}$ przeprowadzonych do tej pory badań są sprzeczne. Dostępne są wyniki badania potwierdzające negatywny wpływ beta-adrenolityków na samopoczucie i nastrój wśród pacjentów leczonych tymi lekami z powodu nadciśnienia tętniczego [87]. W kolejnej pracy metoprololpogłębiał objawy depresyjne i poziom wypaleniazawodowego, ale zapewniał anksjolityczne korzyści niezależne od redukcji akcji serca u pacjentów z przewlekłą niewydolnością serca $\mathrm{z}$ klinicznymi objawami zaburzeń psychicznych [88]. Z tego powodu lekarze muszą zachować czujność, przepisując metoprolol pacjentom z przewlekłą niewydolnością serca, którzy ujawniają doświadczanie zaburzeń psychicznych w wywiadzie.

W meta-analizie, do której włączono 15 randomizowanych badań z udziałem 35000 pacjentów przyjmujących leki beta-adrenolityczne w leczeniu zawału mięśnia sercowego, niewydolności serca lub nadciśnienia tętniczego nie wykazano istotnej statystycznie różnicy między beta-blokerami a placebo $\mathrm{w}$ odniesieniu do objawów depresji. Ponadto beta - blokery wiązały się ze zwiększoną częstością występowania uczucia zmęczenia i dysfunkcji seksualnych [89].

$\mathrm{Na}$ podstawie tych obserwacji postawiono również hipotezę, że leki lipofilne (np. propranolol, metoprolol) wiążą się z większą częstością występowania objawów z ośrodkowego układu nerwowego, takich jak zmęczenie i depresja, ze względu na ich zdolność penetracji do centralnego układu nerwowego. W kolejnych badaniach udowodniono, że zdolność rozpuszczalności betaadrenolityków w lipidach nie wpływała na wzrost ryzyka wystąpienia skutków ubocznych w postaci objawów zaburzeń psychicznych [89].

Z kolei ryzyko wystąpienia zmęczenia, ale nie depresji czy dysfunkcji seksualnej było większe (względne ryzyko 1,78, 95\% CI 1,08-2,93) w porównaniu z beta-blokerami późnej generacji [89]. Należy zwróć uwagę, iż liczba prób była niewielka, a przedziały ufności były dość szerokie.

W kolejnej publikacji będącej wynikiem wieloośrodkowych badań, u pacjentów po zawale mięśnia sercowego oceniono wystąpienie objawów depresji, przy użyciu Kwestionariusza Depresji Becka [90]. U 254 pacjentów przyjmujących beta-blokery i 127 pacjentów nie leczonych beta-blokerami badanie nie wykazało statystycznie istotnej różnicy pomiędzy tymi grupami w zakresie występowania depresji po 3, 6 i 12 miesiącach od zawału mięśnia sercowego [90]. Podobne wyniki uzyskano w publikacji Ranchord’a i współ., również dotyczącej pacjentów po zawale mięśnia sercowego, która nie potwierdziła zwiększenia objawów depresji po 1, 6 i 12 miesiącach terapii beta-blokerami [91]. Tutaj objawy depresji oceniano za pomocą 8-punktowego kwestionariusza zdrowia pacjenta (PHQ-8) u 3190 osób na terapii beta-adrenolitykami i u 280 pacjentów nie stosujących tych leków po zawale mięśnia sercowego [91]. Kent i współ. sugerowali, że beta-blokery mogą częściej powodować depresję u kobiet, niż u mężczyzn [92]. Jednak Crane i współ. zbadali próbkę przekrojową 84 kobiet (> 65 lat) od 6 do 12 miesięcy po zawale mięśnia sercowego i nie stwierdzili podwyższonego ryzyka wystąpienia depresji 
(z zastosowaniem skali geriatrycznej) u kobiet przyjmujących beta-adrenolityki [93].

Do typowych działań niepożądanych kardiologicznych leków beta-adrenolitycznych należą: bradykardia, zmniejszenie wydolności wysiłkowej, niedociśnienie, blokada węzła przedsionkowo-komorowego. Inne typowe działania niepożądane obejmują nudności, wymioty, dyskomfort w jamie brzusznej, zawroty głowy, osłabienie, ból głowy, zmęczenie oraz uczucie suchości w jamie ustnej i oczach. Mniej powszechne działania niepożądane to zaburzenia seksualne, utrata pamięci i dezorientacja [94, 95].

Pomimo tego, że skutki uboczne beta-adrenolityków występują rzadziej w porównaniu do leków z grupy SSRI (między innymi $1-10 \%$ to zaburzenia snu, koszmary senne, przemijające zmęczenie i zimne kończyny) wydaje się, że najrozsądniej byłoby nie odejść od aktualnych wytycznychzalecających SSRI jako lek pierwszego rzutu w leczeniu zaburzeń lękowych, dopóki nie będą dostępne wiarygodne dane dotyczące porównawczej skuteczności i tolerancji obu grup leków [54].

\section{Podsumowanie}

Powyższej przedstawione wyniki dotychczasowych badań wskazują, iż leki adrenolityczne wykazują pewien potencjał anksjolityczny. Analiza prac dotycząca leczenia zaburzeń lęku panicznego i agorafobii sugeruje, iż szczególnie propranolol skutecznie redukuje częstotliwość ataków paniki oraz zmniejsza tendencje do zachowań unikowych u pacjentów z agorafobią. Z kolei liczne badania potwierdziły potencjalne korzyści w zakresie wczesnej interwencji jak i późniejszego leczenia PTSD propranololem. Mimo to dotychczas nie udowodniono terapeutycznego działania propranololu w zaburzeniach lękowych o typie fobii specyficznych. Brakuje także randomizowanych badań klinicznych dotyczących efektu terapeutycznego propranololu w leczeniu innych zaburzeń lękowych. Badania nad innymi lekami beta-adrenolitycznymi wskazują, iż np.: atenolol łagodził objawy lęku u pacjentów cierpiących z powodu izolowanych objawów SAD (ang. social anxiety disorder). Z kolei nadolol zmniejszał objawy tremy w sytuacjach wystąpień publicznych, artystycznych - zbliżone działanie wykazywał również pindolol. Stosowanie betablokerów, głównie litofilnych (np.: propranolol, metoprolol) wiąże się z większą częstością występowania objawów powiązanych z ośrodkowym układem nerwowym (takich jak uczucie chronicznego zmęczenia oraz depresja) ze względu na ich zdolność przenikania do centralnego układu nerwowego, chociaż dostępne są również prace obalające tę tezę.
Resumując można stwierdzić: pomimo, iż leki betaadrenolityczne wykazują pewien potencjał anksjolityczny, wymagają dalszego testowania (w badaniach klinicznych) w celu pomiaru poziomu ich terapeutycznej efektywności, uwzględniając poszczególne rodzaje zaburzeń lękowych.

\section{Conflict of interest}

The authors have declared no conflict of interest.

\section{References}

1. American Psychiatric Association (APA). Diagnostic and Statistical Manual of Mental Disorders, 5th ed.; American Psychiatric Publishing: Arlington, VA, USA, 2013.

2. Moller HJ, Bandelow B, Bauer M, et al. DSM-5 reviewed from different angles: goal attainment, rationality, use of evidence, consequences-part 1: general aspects and paradigmatic discussion of depressive disorders. Eur Arch Psychiatry Clin Neurosci. 2015;265:5-18.

3. Bandelow B. Comparison of the DSM-5 and ICD-10: panic and other anxiety disorders. CNS Spectr. 2017:1-3.

4. Baldwin DS, Gordon R, Abelli M, Pini S. The separation of adult separation anxiety disorder. CNS Spectr. 2016;21:289-294.

5. Diagnostic and Statistical Manual of Mental Disorders, 4th ed. Washington, DC, American Psychiatric Association, 1994.

6. Stein DJ, Scott KM, de Jonge P, Kessler RC. Epidemiology of anxiety disorders: from surveys to nosology and back. Dialogues in clinical neuroscience, 2017;19:127.

7. Baxter AJ, Vos T, Scott KM, Norman RE, Flaxman AD, Blore J et al. The regional distribution of anxiety disorders: implications for the Global Burden of Disease Study, 2010. Int J Methods Psychiatr Res. 2014;23:422-438.

8. Baxter AJ, Scott KM, Vos T, Whiteford HA. Global prevalence of anxiety disorders: a systematic review and meta-regression. Psychol Med. 2013;43(5):897-910.

9. World Health Organization. Depression and other common mental disorders: global health estimates;2017. Dostępna z: http://www. who.int/mental_health/management/depression/prevalence_ global_health_estimates/en/

10. Wittchen HU1, Jacobi F, Rehm J, Gustavsson A, Svensson M, Jönsson B, et al. The size and burden of mental disorders and other disorders of the brain in Europe 2010. Eur. Neuropsychopharmacol. 2011;21:655-679.

11. GBD 2015 Disease and Injury Incidence and Prevalence Collaborators, and others. Global, regional, and national incidence, prevalence, and years lived with disability for 310 diseases and injuries, 1990-2015: a systematic analysis for the Global Burden of Disease Study. The Lancet.2015;388: 1005.

12. Barrera TL, Norton PJ. Quality of life impairment in generalized anxiety disorder, social phobia, and panic disorder. J Anxiety Disord. 2009; 23:1086-1090.

13. Greenberg PE1, Sisitsky T, Kessler RC, Finkelstein SN, Berndt ER, Davidson JR, et al. The economic burden of anxiety disorders in the 1990s. J Clin Psychiatry. 1999; 60(7): 427-435.

14. Wittchen HU, Kessler RC, Beesdo K, Krause P, Höfler M, Hoyer J. Generalized anxiety and depression in primary care: prevalence, recognition, and management. J Clin Psychiatry. 2002; 63 Suppl.8:24-34 
15. Remes O, Brayne C, Van Der Linde R, Lafortune L. A systematic review of reviews on the prevalence of anxiety disorders in adult populations. Brain and Behavior. 2016;6:e00497.

16. Simpson HB, Neria Y, Lewis-Fernandez R, Schneier F. Anxiety disorders - theory, research and clinical perspectives. 1st ed. Cambridge University Press, Cambridge.2010.

17. Bandelow B, ReittM,Röver C, Michaelis S, Görlich Y, WedekindD. Efficacy of treatments for anxiety disorders: a meta-analysis. International Clinical Psychopharmacology. 2015;30:183-192.

18. Huang BT, Huang FY, Zuo Z, Liao YB, Heng Y, Wang PJ, et al. Metaanalysis of relation between oral $\beta$-blocker therapy and outcomes in patients with acute myocardial infarction who underwent percutaneous coronary intervention. The American journal of cardiology. 2015;115:1529-1538.

19. Task Force Members.2014 ESC/ESA Guidelines on non-cardiac surgery: cardiovascular assessment and management: The Joint Task Force on non-cardiac surgery: cardiovascular assessment and management of the European Society of Cardiology (ESC) and the European Society of Anaesthesiology (ESA). European heart journal. 2006;35:2383-2431.

20. Moran NC, Perkins ME. Adrenergic blockade of the mammalian heart by a dichloroanalogue of isoproterenol. Journal of pharmacology and experimental therapeutics.1958;124: 223-237.

21. William H., Frishman WH. Fifty years of beta-blockers: a revolution in CV pharmacotherapy. Cardiology Today. December 2008.

22. Black JW, Crowther AF, Shanks RG, Smith LH, Dornhost AC. A new adrenergic: beta-receptor antagonist. The Lancet. 1964;283:10801081.

23. Yusuf S, Peto R, Lewis J, Collins R, Sleight P. Beta blockade during and after myocardial infarction: an overview of the randomized trials. Progress in cardiovascular diseases1985; 27:335-371.

24. Julian DG, Jackson FS, Prescott RJ, Szekely P. Controlled trial of sotalol for one year after myocardial infarction. The Lancet. 1982; 319: $1142-1147$

25. Hjalmarson A, Elmfeldt D, Herlitz J, Holmberg S, Málek I, Nyberg G, et al. Effect on mortality of metoprolol in acute myocardial infarction: a double-blind randomised trial. The Lancet. 1981;318: 823-827.

26. Frishman WH, Ruggio J, FurbergC. Use of beta-adrenergic blocking agents after myocardial infarction. Postgraduate medicine. 1985;78:40-53.

27. Veterans Administration Co-operative Study Group. Comparison of propranolol and hydrochlorothiazide for the initial treatment of hypertension. I. Results of short-term titration with emphasis on racial differences in response. JAMA. 1982;248:1996-2003.

28. Domanski MJ, Krause-Steinrauf H, Massie BM, Deedwania P, Follmann D, Kovar Det al. A comparative analysis of the results from 4 trials of $\beta$-blocker therapy for heart failure: BEST, CIBIS-II, MERITHF, and COPERNICUS. Journal of cardiac failure. 2003;9:354-363

29. Dooley TP. Treating anxiety with either beta blockers or antiemetic antimuscarinic drugs: a review. Mental Health in Family Medicine. 2015;11:89-99.

30. Kuch M, Syska-Sumińska J. Leki beta-adrenolityczne - zastosowanie kliniczne. W:Braksator W i in. Kardiologia praktyczna: dla lekarzy rodzinnych i studentów medycyny. T. 2, Farmakologia kliniczna. Warszawa: Akademia Medyczna, 2002. s. 43.

31. Freemantle N, Cleland J, Young P, Mason J, Harrison J. Beta-blockade after myocardial infarction: systematic review and meta regression analysis. BMJ 1999;26: 1730-37.

32. MERIT-HF Study Group. Effect of metoprolol CR/XL in chronic heart failure: Metoprolol CR/XL Randomised Intervention Trial in-
Congestive Heart Failure (MERIT-HF). Lancet. 1999;353:2001-7.

33. Packer M, Coats AJS, Fowler MB, Katus HA, Krum H, Mohacsi P et al. Effect of carvedilol on survival in severe chronic heart failure. N Engl J Med 2001;344:1651-8.

34. Di Lenarda A, Sabbadini G, Salvatore L, Sinagra G, Mestroni L, Pinamonti B et al. Long-term effects of carvedilol in idiopathic dilated cardiomyopathy with persistent left ventricular dysfunction despite chronic metoprolol. J Am Coll Cardiol. 1999; 33:1926-34.

35. Bangalore S, Messerli FH, Kostis JB, Pepine CJ. Cardiovascular protection Rusing beta-blockers: a critical review of the evidence. J Am Coll Cardiol. 2007;50:563-72.

36. Turner P, Granville-Grossman KL Effect of adrenergic receptor blockade of the tachycardia of thyrotoxicosis and anxiety state. Lancet. 1965;2:1316-1318

37. Becker AL. Oxprenolol and propranolol in anxiety states. A doubleblind comparative study. S Afr Med J.1976;50: 627-629.

38. Meibach RC, Dunner D, Wilson LG, Ishiki D, Dager SR. Comparativeefficacy of propranolol, chlordiazepoxide, and placebo in the treatment ofanxiety: A double-blind trial. J Clin Psychiatry. 1987;48:355-358.

39. Wheatley D. Comparative effects of propranolol and chlordiazepoxide in anxiety states. Br J Psychiatry 1969;115:14111412.

40. Brewer C. Beneficial effect of beta-adrenergic blockade on 'exam nerves'. Lancet 1972;2:435.

41. Drew PJ, Barnes JN, Evans SJ. The effect of acute betaadrenoceptorblockade on examination performance. $\mathrm{Br} \mathrm{J}$ Clin Pharmacol 1985;19:783-786.

42. Clark DB, AgrasWS.The assessment and treatment of performanceanxiety in musicians. Am J Psychiatry 1991;148:598605.

43. Brantigan CO, Brantigan TA, Joseph N. Effect of beta blockadeand beta stimulation on stage fright. Am J Med.1982;72: 88-94.

44. Elman MJ, Sugar J, Fiscella R, Deutsch TA, Noth J, Nyberg Met al. The effect of propranolol versusplacebo on resident surgical performance. Trans Am Ophthalmol Soc96: 283-291; discussion 1998;291-294.

45. Dyck JB, Chung F.A comparison of propranolol and diazepamfor preoperative anxiolysis. Can J Anaesth. 1991;38:704-709.

46. MacKinnon DF, Craighead B, Hoehn-Saric R. Carbon dioxide provocation of anxiety and respiratory response in bipolar disorder. Journal of affective disorders 2007;99: 45-49.

47. Papp LA, Martinez JM, Klein DF, Coplan JD, Norman RG, Cole Ret al. Respiratory psychophysiology of panic disorder: three respiratory challenges in 98 subjects. Am J Psychiatry. 1997;154.11: 15571565.

48. Strohle A, Kellner M, Yassouridis A. Effect of flumazenil in lactatesensitive patients with panic disorder. Am J Psychiatry.1998;155: 610-612.

49. Kronenberg G, Schredl M, Fiedler K. In healthy volunteers responses to challenge with cholecystokinin tetrapeptide differ between administration during REM and delta sleep. Depress Anxiety 2001;14:141-144.

50. Papadopoulos A, Rich A, Nutt DJ. The effects of single dose anxiolytic medication on the $\mathrm{CO} 2$ models of anxiety: differentiation of subjective and objective measures. Journal of psychopharmacology 2010; 24: 649-656.

51. Ravaris CL, Friedman MJ, Hauri PJ. A controlled study of alprazolam and propranolol in panic-disordered and agoraphobic outpatients. J Psychopharmacol. 1991;11:344-350.

52. Steenen SA., van Wijk AJ, Van Der Heijden GJ, van Westrhenen 
$\mathrm{R}$, de Lange J, de Jongh A. Propranolol for the treatment of anxiety disorders: Systematic review and meta-analysis. J Psychopharmacol. 2016;30:128-139.

53. Baldwin DS, Anderson IM, Nutt DJ, Allgulander C, Bandelow B, et al. Evidence-based pharmacological treatment of anxiety disorders, post-traumatic stress disorder and obsessive-compulsive disorder: a revision of the 2005 guidelines from the British Association for Psychopharmacology. J Psychopharmacol., 2014;28:403-439.

54. Johansen JP, Cain CK, Ostroff LE, LeDoux JE. Molecular mechanisms of fear learning and memory. Cell 2011;147:509-524.

55. Kindt M, Soeter M and Vervliet B. Beyond extinction: Erasing human fear responses and preventing the return of fear. Nat Neurosci. 2009;12:256-258.

56. Soeter M and Kindt M. Dissociating response systems: Erasing fear from memory. Neurobiol Learn Mem. 2010;94:30-41

57. McGaugh JL. Memory - a century of consolidation. Science. 2000;287:248-251.

58. Cahill L, Prins B, Weber M, McGaugh JL. $\beta$-adrenergic activation and memory for emotional events. Nature 1994;371:702-704.

59. Van Stegeren AH, Everaerd W, Cahill L, McGaugh JL, Gooren LJ. Memory for emotional events: differential effects of centrally versus peripherally acting $\beta$-blocking agents. Nature 1998;138:305-310.

60. Van Stegeren AH, Goekoop R, Everaerd W. Scheltens P, Barkhof F, Kuijer JP et al. Norepinephrine mediates amygdala activation in men and women during encoding of emotional material. Neuroimage 2005;24:898-909.

61. Strange BA, Dolan RJ. B-adrenergic modulation of emotional memory-evoked human amygdala and hippocampal responses. Proc. NatlAcad. Sci. USA 2004;101:11454-11458.

62. Hurlemann R, Walter H, Rehme AK, Kukolja J, Santoro SC, Schmidt $\mathrm{C}$ et al. Human amygdala reactivity is diminished by the $\beta$-noradrenergic antagonist propranolol. Psychological medicine. 2010;40:1839-1848.

63. Rimmele U, Lackovic SF, Tobe RH, Leventhal BL Phelps EA. Betaadrenergic blockade at memory encoding, but not retrieval, decreases the subjective sense of recollection. Journal of cognitive neuroscience, 2016;28:895-907.

64. Schwabe L, Nader K, Wolf OT, Beaudry T, Pruessner JC. Neural signature of reconsolidation impairments by propranolol in humans. Biol Psychiatry. 2012;71:380-386.

65. Mahabir M, Ashbaugh AR, Saumier D , Tremblay J. Propranolol's impact on cognitive performance in post-traumatic stress disorder. J Affect Disord. 2016;192:98-103.

66. Hoge EA, Worthington JJ, Nagurney JT. Effect of acute posttrauma propranolol on PTSD outcome and physiological responses during script-driven imagery. CNS Neurosci Ther.2012;18:21-27.

67. Bell J. Propranolol, post-traumatic stress disorder and narrative identity. J Med Ethics.2008;34:e23.

68. Falloon IR, Lloyd GG, Harpin RE. The treatment of social phobia. Real-life rehearsal with nonprofessional therapists. J Nerv Mental Dis. 1981;169:180-184.

69. Neftel KA, Adler RH, Kappeli L. Stage fright in musicians: a model illustrating the effect of beta blockers. Psychosom Med. 1982; 44:461-469.

70. James I, Savage I. Beneficial effect of nadolol on anxietyinduced disturbances of performance in musicians: a comparison with diazepam and placebo. Am Heart J.1984;108:1150-1155.

71. Gates GA, Saegert J, Wilson N. Effect of beta blockade on singing performance. Ann OtolRhinolLaryngol.1985;94: 570-574.

72. James IM, Burgoyne W, Savage IT. Effect of pindolol on stress-related disturbances of musical performance: preliminary communication. J RSocMed.1983;76:194-196.

73. Swartz CM. Betaxolol in anxiety disorders. Ann Clin Psychiatry.1998;10:9-14.

74. Hallas CN, Wray J, Andreou P, Banner NR. Depression and perceptions about heart failure predict quality of life in patients with advanced heart failure. Heart Lung, 2011; 40:111-121.

75. Pajak A, Jankowski P, Kotseva K, Heidrich J, De Smedt D, De Bacquer D. Depression, anxiety, and risk factor control in patients after hospitalization for coronary heart disease: the EUROASPIRE III Study. Eur J PrevCardiol.2013;20:331-340.

76. Aburuz, ME. Anxiety and depression predicted quality of life among patients with heart failure. Journal of multidisciplinary healthcare, 2018, 11: 367.

77. Celano CM, Millstein RA, Bedoya CA, Healy BC, Roest AM, Huffman JC. Association between anxiety and mortality in patients with coronary artery disease: a meta-analysis. Am Heart J. 2015;170:1105-15.

78. Małyszczak, K; Rymaszewska, J. Depression and anxiety in cardiovascular disease. Kardiologia Polska (Polish Heart Journal), 2016, 74.7: 603-609.

79. Emdin, CA., et al. Meta-analysis of anxiety as a risk factor for cardiovascular disease. The American journal of cardiology, 2016, 118.4: 511-519

80. Moser DK. "The rust of life": impact of anxiety on cardiac patients. Am J CritCare, 2007;16:361-369.

81. Moser DK., McKinley S, Riegel B, Doering LV, Meischke H, Pelter M, Dracup K. Relationship of persistent symptoms of anxiety to morbidity and mortality outcomes in patients with coronary heart disease. Psychosom Med. 2011;73: 803-809.

82. Yekehtaz, H; Farokhnia, M; Akhondzadeh, S. Cardiovascular considerations in antidepressant therapy: an evidence-based review. The Journal of Tehran University Heart Center, 2013, 8.4: 169.

83. Dharmarajan TS, Dharmarajan L. Tolerability of Antihypertensive Medications in Older Adults. Drugs Aging.2015;32:773-796.

84. Kubesova HM, Weber P, Meluzinova H, Bielakova K, Matejovsky J. Benefits and pitfalls of cardiovascular medication in seniors. Wiener klinischeWochenschrift. 2013;125:425-436.

85. Crocco EA, Jaramillo S, Cruz-Ortiz C, Camfield K. Pharmacological Management of Anxiety Disorders in the Elderly. CurrTreatOptions Psychiatry. 2017;4:33-46.

86. Molden E, SpigsetaO. Interactions between metoprolol and antidepressants. Tidsskr Nor Laegeforen. 2011;131:1777-9

87. Boal AH, Smith DJ, McCallum L, Muir S, Touyz RM, Dominiczak AF et al. Monotherapy With Major Antihypertensive Drug Classes and Risk of Hospital Admissions for Mood Disorders. Hypertension. 2016;68:1132-1138.

88. Liu X, Lou X, Cheng X, Meng Y. Impact of metoprolol treatment on mental status of chronic heart failure patients with neuropsychiatric disorders. Drug Des DevelTher. 201711:305-312.

89. Ko DT, Hebert PR, Coffey CS, Sedrakyan A, Curtis JP, Krumholz HM : B-blocker therapy and symptoms of depression, fatigue, and sexual dysfunction. JAMA. 2002; 288:351-357

90. Joost P van Melle JP, Verbeek DEP, van den Berg MP, Ormel J, van der Linde MR, de Jonge. Beta-blockers and depression after myocardial infarction. J Am Coll Cardiol. 2006;48:2209-2214.

91. Ranchord AM, Spertus JA, Buchanan DM, Gosch KL, Chan PS.Initiation of $\beta$-blocker therapy and depression after acute myocardial infarction. Am Heart J. 2016;174:37-42. 
92. Kent LK, Weston CA, Heyer EJ, Sherman W, Prudic J.Successful retrial of ECT two months after ECT-induced takotsubo cardiomyopathy. Am J Psychiatry. 2009; 166:857-862.

93. Crane PB, Oles KS, Kennedy-Malone L. Beta-blocker medication usage in older women after myocardial infarction. J Am Acad Nurse Pract 2006;18:463-470.

94. Tucker WD, Whitten RA. Selektywne Beta -1 blokery. Stat Pearls [Internet]. Treasure Island (FL):StatPearls Publishing 2018.

95. Roy-Byrne P, Stein M, Hermann R. Farmakoterapia na zespół lęku napadowego.W:PostT,redaktornaczelny.(red.)UpToDate.Waltham, MA : Up To Date dostępne na stronie : http://www.uptodate.com/ contents/pharmacotherapyforpanicdisorder (dostęp 9 lipca 2015 r.)

\section{Correspondence adress:}

Żaneta Brudkowska,

Zakład Neuropsychiatrii Klinicznej

Uniwersytetu Medycznego w Lublinie

ul. Głuska 1, 20-439 Lublin, Polska,

mail: brudkowskaz@gmail.com

Otrzymano: 28.09.2018

Zrecenzowano: 11.10 .2018

Przyjęto do druku: 27.11.2018 